\title{
Does brainstem-derived serotonin mediate GLP-1 receptor agonist-induced suppression of appetite and body weight via 5-HT2A receptors?
}

\author{
Katsunori Nonogaki* \\ Department of Diabetes Technology, Tohoku University Graduate School of Biomedical Engineering, Japan
}

Brain serotonin (5-HT) systems have a critical role in the regulation of appetite and body weight. Central serotonin 5-HT2C receptors contribute to the leptin-independent regulation of appetite [1]. On the other hand, central 5-HT2B and 5-HT1A receptors have implicated in the leptin-dependent regulation of appetite [2]. The recent article by Anderberg et al. [3] suggested that brain-derived serotonin is a critical mediator of the weight loss induced by GLP-1 receptor activation, and that central 5-HT2A receptors mediate the chronic anorexic and weight loss effects of central injection of exedin-4 (EX4) or of intraperitoneal injection of liraglutide. We question their results and conclusions.

First, can increases in brainstem-derived 5-HT induce body weight reduction and feeding suppression? Brainstem 5-HT content and TPH2 expression are increased in ob/ob mice compared with wild-type mice [2]. Genetic inhibition of 5-HT synthesis in the brainstem decreases food intake and body weight in ob/ob mice and wild-type mice [2]. In addition, pharmacologic inhibition of 5-HT synthesis in the brainstem induced by treatment with a high dose of p-chlorophenylalanine (PCPA) $(500 \mathrm{mg} / \mathrm{kg})$ or trans-2 PCPA decreases body weight and food intake in C57BL6J mice, db/db mice [4], and high-fat-diet-induced obesity [5]. Thus, depletion of brainstem-derived 5-HT leads to decreases in body weight and energy intake in mice. Moreover, treatment with PCPA for 3 days does not permanently deplete brain-derived 5-HT content and it gradually recovers. It is unclear whether depletion of the brainstem 5-HT content induced by treatment with a low dose of PCPA (100 mg/ $\mathrm{kg}$ ) for 3 days can be sustained for 5 days.

Second, can 5-HT2A receptors mediate body weight reduction and feeding suppression induced by GLP-1 analogs? Previous results of pharmacologic and genetic studies do not provide that central 5-HT2A receptors downregulate food intake and body weight.

Anorexic effects of a 5-HT2A receptor agonist, TCB-2, are only observed at the highest dose, and do not appear to be dose-dependent [6]. Thus, these effects of high-dose TCB-2 might be due to toxic or non-specific effects. 5-HT2A receptor-deficient mice do not exhibit altered body weight and food intake, as the authors described in their discussion [3].

Copyright: (C2017 Nonogaki K. This is an open-access article distributed under the terms of the Creative Commons Attribution License, which permits unrestricted use, distribution, and reproduction in any medium, provided the original author and source are credited.
Although the authors showed that the 5-HT2A receptor antagonist reversed the decreases in body weight and food intake induced by EX4 and liraglutide, EX4 suppressed the increased expression of hypothalamic 5-HT2A receptors induced by food restriction [3]. Do GLP-1 analogs increase the expression of hypothalamic 5-HT2A receptors in freely-fed rats?

Moreover, the degree of weight loss induced by EX4 alone in the study using R-96544, a 5-HT2A receptor antagonist, was much greater than that in the study using SB242084, a selective 5-HT2C receptor antagonist (3-fold decrease). This difference leads to significant differences in body weight changes between the EX4 group and 5-HT2A receptor antagonist/EX4 group. The effects of the 5-HT2A receptor antagonist on GLP-1 analogs should be re-examined. Thus, the results and conclusions that brain-derived 5-HT mediates the decreases in body weight and food intake induced by GLP-1 analogs via 5-HT2A receptors are questionable, and further studies are needed to ensure the reliability of the reported findings.

\section{References}

1. Nonogaki K, Strack AM, Dallman MF, Tecott LH (1998) Leptin-independen hyperphagia and type 2 diabetes in mice with a mutated serotonin 5-HT2C receptor gene. Nat Med 4: 1152-1156. [Crossref]

2. Yadav VK, Oury F, Suda N, Liu ZW, Gao XB, et al. (2009) Leptin regulation of bone mass, appetite and energy expenditure relies on its ability to inhibit serotonin synthesis in the brainstem. Cell 138: 976-989. [Crossref]

3. Anderberg RH, Richard JE, Eerola K, López-Ferreras L, Banke E, et al. (2017) Glucagon-like peptide 1 and its analogs act in the dorsal raphe and modulate central serotonin to reduce appetite and body weight. Diabetes 66: 1062-1073. [Crossref]

4. Nonogaki K, Kaji T (2016) The acute anorexic effect of liraglutide, a GLP-1 receptor agonist, does not require functional leptin receptor, serotonin, and hypothalamic POMC and CART activities in mice. Diabetes Res Clin Pract 120: 186-189. [Crossref]

5. Shemesh A, Abdulla A, Yang F, Chua SC, Pessin JE, et al. (2014) The antidepressan trans-2 phenylcyclopropylamine protects mice from high-fat-diet-induced obesity. PLOS One 9: e89199. [Crossref]

6. Fox MA, French HT, LaPorte JL, Blacler AR, Murphy DL (2010) The serotonin 5-HT2A receptor agonist TCB-2: a behavioral and neurophysiological analysis. Psychopharmacology 212: 12-23. [Crossref]

Correspondence to: Katsunori Nonogaki, Professor, Department of Diabetes Technology, Tohoku University Graduate School of Biomedical Engineering, 6-6-11 Aramakiaza-aoba, Aoba-ku, Sendai, Miyagi 980-8579, Japan, Tel: +8122-795-3865; Fax: +81-22-795-3865; E-mail: katsu@trc.med.tohoku.ac.jp

Received: July 02, 2017; Accepted: July 25, 2017; Published: July 27, 2017 